\title{
Adherence to tuberculosis treatment in Primary Health Care: perception of patients and professionals in a large municipality
}

\author{
Adesão ao tratamento da tuberculose na Atenção Básica: percepção de doentes e profissionais em \\ município de grande porte
}

\section{Adhesión a tratamiento antituberculoso en Atención Primaria de Salud: percepción de enfermos y profesionales en municipio importante}

\author{
Aline Ale Beraldo \\ Rubia Laine de Paula Andrade ${ }^{1}$ \\ Nathália Halax Orfão ${ }^{2}$ \\ Reinaldo Antônio da Silva-Sobrinho ${ }^{3}$ \\ Érika Simone Galvão Pinto ${ }^{4}$ \\ Anneliese Domingues Wysocki ${ }^{5}$ \\ Maria Eugênia Firmino Brunello ${ }^{1}$ \\ Aline Aparecida Monroe ${ }^{1}$ \\ Lúcia Marina Scatena ${ }^{6}$ \\ Tereza Cristina Scatena Villa ${ }^{1}$
}

\section{Universidade de São Paulo.}

Ribeirão Preto, São Paulo, Brazil.

2. Universidade Federal de Rondônia.

Porto Velho, Rondônia, Brazil.

3. Universidade Estadual do Oeste do Paraná.

Foz do Iguaçu, Paraná, Brazil.

4. Universidade Federal do Rio Grande do

Norte. Natal, Rio Grande do Norte, Brazil.

5. Universidade Federal do Mato Grosso do

Sul. Três Lagoas, Mato Grosso do Sul, Brazil.

6. Universidade Federal do Triângulo Mineiro.

Uberaba, Minas Gerais, Brazil.
Corresponding author:

Aline Ale Beraldo.

E-mail: li_aab@yahoo.com.br

Submitted on 05/26/2017.

Accepted on 07/19/2017.

DOI: 10.1590/2177-9465-EAN-2017-0075

\begin{abstract}
Objective: Analyze the actions developed in Primary Health Care (PHC) to promote adherence to tuberculosis (TB) treatment in the perception of patients and nursing team. Methods: Cross-sectional epidemiological study conducted at the PHC of Campinas-SP, through structured interviews with 18 corresponding questions on the perception of professionals (183) and patients (165). Chi-square test and Fisher's exact test were used. Results: Actions such as the promotion of autonomy and time for the patient to talk about doubts and concerns, guidance to seek information in books and/or on the Internet on the disease, and for the family to perform TB tests, undergo directly observed treatment, schedule monthly consultations, delivery of written information on treatment and incentive were actions more perceived by the professionals than patients reported receiving. Conclusions: The identification of gaps in the offer of actions for adherence to TB treatment can help health services to change and improve the practice and the epidemiological scenario of the disease.
\end{abstract}

Keywords: Tuberculosis; Primary Health Care; Medication Adherence; Nursing Team.

\section{Resumo}

Objetivo: Analisar as ações desenvolvidas nos serviços de Atenção Básica (AB) para promover a adesão ao tratamento da Tuberculose (TB) na percepção de doentes e profissionais de enfermagem. Métodos: Estudo epidemiológico transversal, realizado na $\mathrm{AB}$ de Campinas-SP, por meio de entrevista estruturada com 18 questões correspondentes na percepção de profissionais (183) e doentes (165). Utilizou-se teste qui-quadrado e exato de Fisher. Resultados: Ações como a promoção de autonomia e tempo para o doente falar de dúvidas e preocupações, familiar realizar exames para a TB, realização de tratamento diretamente observado, agendamento de consulta mensal, entrega de informação escrita sobre o tratamento, oferta de incentivo foram ações mais percebidas pelos profissionais, do que os doentes afirmaram receber. Conclusões: A identificação de lacunas na oferta de ações para a adesão ao tratamento da TB pode ajudar os serviços de saúde a modificar e melhorar a prática e o cenário epidemiológico da doença.

Palavras-chave: Tuberculose; Atenção Primária à Saúde; Adesão à medicação; Equipe de Enfermagem.

\section{Resumen}

Objetivo: Analizar acciones desarrolladas en servicios de Atención Primaria de Salud (APS) para promover adhesión al tratamiento de Tuberculosis (TB) en visión de enfermos y profesionales de enfermería. Métodos: Estudio epidemiológico transversal, realizado en APS de Campinas-SP, mediante entrevista estructurada de 18 preguntas pertinentes a percepción de profesionales (183) y enfermos (165). Se aplicó test Chi-cuadrado y exacto de Fisher. Resultados: Acciones como promoción de autonomía y tiempo para consultas de dudas y preocupaciones del enfermo, para que el familiar realice exámenes de TB, ejecución de tratamiento directamente observado, agendado de consulta mensual, entrega de información escrita sobre tratamiento y oferta de incentivo, fueron acciones más observadas por los profesionales que por los enfermos. Conclusiones: La identificación de vacíos en la oferta de acciones de adhesión al tratamiento de TB puede colaborar a que los servicios de salud modifiquen y mejoren la práctica y el escenario epidemiológico de la enfermedad.

Palabras clave: Tuberculosis; Atención Primaria de Salud; Cumplimiento de la Medicación; Grupo de Enfermería. 


\section{INTRODUCTION}

Tuberculosis (TB) is considered a chronic communicable condition of long-term treatment. The main difficulties for cure are the non-adherence or abandonment of the treatment. ${ }^{1}$ The disease control is the responsibility of municipalities and competence of the Primary Health Care (PHC) system. ${ }^{2}$ Brazil has met the goal of $70 \%$ of case detection proposed by the World Health Organization (WHO) until 2015, but has failed in reaching the $85 \%$ cure rate and abandonment rate lower than $5 \%$.

In 2015, Brazil presented 63,189 new TB cases notified and coefficient of incidence of 30.9 cases $/ 100,000$ inhabitants; rate of cure of $72.5 \%$, and an $11.0 \%$ rate of treatment abandonment. It is ranked $18^{\text {th }}$ in TB burden accounting for $0.9 \%$ of the estimated cases in the world and $33 \%$ in the American continent. ${ }^{3}$

In this light, adherence to treatment comprises not only adherence to medication intake, but to a dynamic and multidimensional process that involves behavioral, psychic and social aspects, demanding decisions and responsibilities that are shared among users, health team, and the supporting network. The approach should consider the individuals' singularities, ${ }^{4,5}$ gathering the guidance and fitting of the therapeutic schedules to the patients' lifestyle, as well as to their family, social and even emotional support. ${ }^{6}$ To effectively control TB the patient's behavior during the cure process must be appraised and is likely to be the main factor of therapeutic success. ${ }^{4}$

Moreover, adherence includes professional-related factors such as health actions focused on the individual rather than exclusively on procedures, gathering guidance, fitting of therapeutic schedules to the patient's lifestyle, clarifications, and social support. ${ }^{6}$ Here, the nursing team deserves special attention because of their historical context of TB cases' management, and actions aimed at TB prevention, control and elimination. These professionals ensure the directly observed treatment (DOT) avoiding complications that could favor abandonment, recurrence, failure and resistant TB. ${ }^{7}$

Literature discloses different approaches to the actions promoted by $\mathrm{PHC}$ to promote adherence to the TB treatment. A bibliographic survey was conducted on the LILACS, MEDLINE, Cinahl, Scopus, IBECS databases and on the SciELO virtual library using the descriptors "Tuberculosis", "Medication Adherence", "Treatment Refusal", "Patient Dropouts", "Patient Compliance" and "Treatment Failure", oriented by the question: "What is the scientific evidence on aspects related to the dimensions of adherence to TB treatment?". Of the 323 articles found, 31 were selected according to the following criteria: being an original research article of national and international origin with the abstract available in the selected databases and virtual library, published in Portuguese, Spanish and/or English from 2008 to 2012, and which did not approach TB in children.

Of the 31 selected articles, 20 used the quantitative approach, being 11 (35.5\%) cross-sectional; five (16.1\%) cohort; and, four (12.9\%) case-control studies. Other 11 articles used the qualitative approach. Patients were the study population of most studies 25 (80.6\%), of which 18 (90\%) with quantitative approach and seven (63.6\%) qualitative studies; four (12.9\%) articles' population of study comprised patients and health professionals, all in a qualitative approach and none carried out in Brazil; and two (6.5\%) articles had health professionals as the study population.

Considering the multidimensional concept of adherence to treatment proposed by the $\mathrm{WHO},{ }^{4}$ the aspects that cause non-adherence to treatment were approached in 19 quantitative studies (95\%) and in 8 quantitative studies (73\%).

In the quantitative studies, the socioeconomic (education and sex) and patient's dimensions (lack of knowledge about TB and of engagement in treatment, lack of family support) were the most prominent, followed by the dimensions of treatment (length, side effect of medications and symptom improvement), disease (use of alcohol, drugs and tobacco, resistant TB, extra-pulmonary TB, HIV/AIDS), and health systems and teams (hostility, lack of professional training, lack of supervision of the medication).

In addition to the patient, sociodemographic and treatment dimensions, the qualitative studies highlight aspects such as the actions of healers vs. traditional medicine, use of herb-based medications, stigma and prejudice perceived by patients.

The literature review unveiled gaps in the production of studies about adherence to TB treatment showing the patients and health professionals' perception. Therefore, this paper aimed to analyze the actions developed in $\mathrm{PHC}$ services to promote adherence to TB treatment from the perception of patients and nursing professionals.

\section{METHOD}

A cross-sectional epidemiological study was carried out in Campinas, in the state of São Paulo, which is one of the 42 priority municipalities for TB control in the state of São Paulo. ${ }^{6}$ In 2013, Campinas notified 299 new cases of TB with a coefficient of incidence of 26.2 cases per 100,000 inhabitants; $82.3 \%$ of cure; $8.3 \%$ of abandonment and $8 \%$ of death, of which $4.7 \%$ from TB. ${ }^{8,9}$

During data collection (August 2012 to May 2013) the municipality had 63 Health Centers (HC) with 155 Family Health Teams (FHT) decentralized into five sanitary districts with District Health Surveillance (VISA). Each HC was made up of a manager, a co-manager and multiprofessional teams, with physicians (practitioners, pediatricians, gynecologists-obstetricians), nurses, nursing aides/technicians, community health workers $(\mathrm{CHW})$, dentists, and dentist office clerks.

The HC are supported by the VISA's teams and carry out activities to seek respiratory patients; request and collect exams for diagnostic support; medical and nursing appointments; DOT; medications supply; referral to other services for X-rays and visit to specialists. 
The study population was made up of TB patients, according to the following inclusion criteria: being in TB treatment for three months or longer at the PHC of the municipality; living in the municipality of Campinas; being 18 years old or older; not being a prisoner. Of the 349 TB patients undergoing treatment in Campinas during the data collection period, 165 participated in the study. Of the total registered, 159 did not meet the inclusion criteria (one prisoner, 15 children, 139 were treated in reference units or hospitals, and four had ended treatment), eight died, five were transferred to another city, five could not be found, four abandoned the treatment and the service team asked us not to interview three TB patients.

The nursing team professionals participated in the study were nurses, nursing aides or technicians working in the $\mathrm{PHC}$ services of the municipalities who had assisted any TB case in the last 12 months prior to data collection. A total of 214 nursing professionals were recommended to participate in the research. However, 16 refused to participate and 15 reported having never assisted any TB case. Therefore, 183 professionals were interviewed.

Data were collected through interviews, and the study nature and objective were explained to each respondent that was invited to participate by signing a free and informed consent form. Interviews were carried out in the $\mathrm{HC}$, on sites recommended by the professionals, safeguarding the respondents' privacy. Some interviews were carried out at the TB patients' residence, whenever they required.

To identify the actions developed by the PHC services to promote adherence to the TB treatment, two structured instruments were used: one to the TB patients and another to the nursing professionals. Each tool comprised 18 questions to interview the patients and the nursing professionals (guidance about what is TB; guidance to seek information about the disease in books and/or on the Internet; opportunity for the TB patient to speak about the treatment; scheduling of monthly appointments to monitor treatment; guidance about the importance of keeping monthly appointments; guidance about undergoing control exams; guidance about how the TB medicines should be taken; delivery of written information about the treatment to patients; encouragement to continue the TB treatment; instruction to TB patients to seek the health service in case of doubts about the treatment; guidance to observe if symptoms improve during treatment; guidance about what to do if symptoms worsen; guidance about habits to be adopted to have a healthier life; guidance for family members to undergo TB exams; time to talk about doubts and/or concerns; offering of DOT; incentive to undertake treatment; invitation to participate in a group of TB patients). It is worth mentioning that such instruments had dichotomist response categories (yes and no).

Each instrument had questions to describe the profile of TB patients (sex, age, education, housing, living arrangement, type of case, clinical form, use of alcohol and tobacco) and nursing professionals (professional category, sex, age, training courses, search for information about TB in books and/or on the internet). These instruments were designed based on the multidimensional concept of adherence to treatment ${ }^{4}$ and other documents ${ }^{10-14}$ adapted to TB health care. The referential of adherence and its many dimensions were used and, thus, some of the studied actions may seem not to fit into this concept if we think strictly on medication adherence. However, it considered aspects related to the treatment and health system, such as disease and treatment management jointly with patients; flexibility in the treatment available; awareness-raising of TB patients about the treatment and, supervision and monitoring of treatment.

The analysis of profiles for TB patients and the nursing professionals used exploratory analysis techniques (frequency distribution, central tendency measures and variability). The analysis of association of the TB patients' and nursing professionals' perception about the actions developed to promote adherence to the TB treatment employed the chi-square test and Fisher's exact test whenever the criterion of $20 \%$ of the expected value $E_{i j} \geq 5$ was not met. ${ }^{15}$ The responses of patients and professionals were considered concordant when there was not a significant statistical association $(p>0.05)$ to the tests performed, and discordant for a significant statistical association $(p<0.05)$.

The survey was authorized by the Municipal Health Department of the studied municipality and approved by a research ethics committee according to protocol \# 1.264/2011.

\section{RESULTS}

The profiles of the TB patients interviewed are presented in Table 1. Their mean age was $39[\mathrm{IQ}=29 ; 50]$ years.

The profile of the professionals interviewed is presented in Table 2. The mean age of professionals was $37.0[I \mathrm{Q}=29 ; 46]$ years.

The analysis on the association of the TB patients' and the nursing team professionals' perceptions about the actions developed to promote adherence to the TB treatment is presented in table 3.

\section{DISCUSSION}

This study found that 10 of the 18 actions developed in the $\mathrm{PHC}$ service to promote patient adherence to the treatment were concordant among patients and nursing professionals.

Regarding guidance about what TB is, patients and professionals have respectively received and offered this action, acknowledging this may have been facilitated because the TB patients had eight or more years of education. Moreover, it emphasizes the professionals' efforts to deliver training and seek information about TB in books and/or on the Internet, which is an important matter in the light of access to TB-related educational programs. 
Table 1. Distribution of frequencies of the profile of tuberculosis patients under treatment, Campinas - São Paulo, Brazil, 2013.

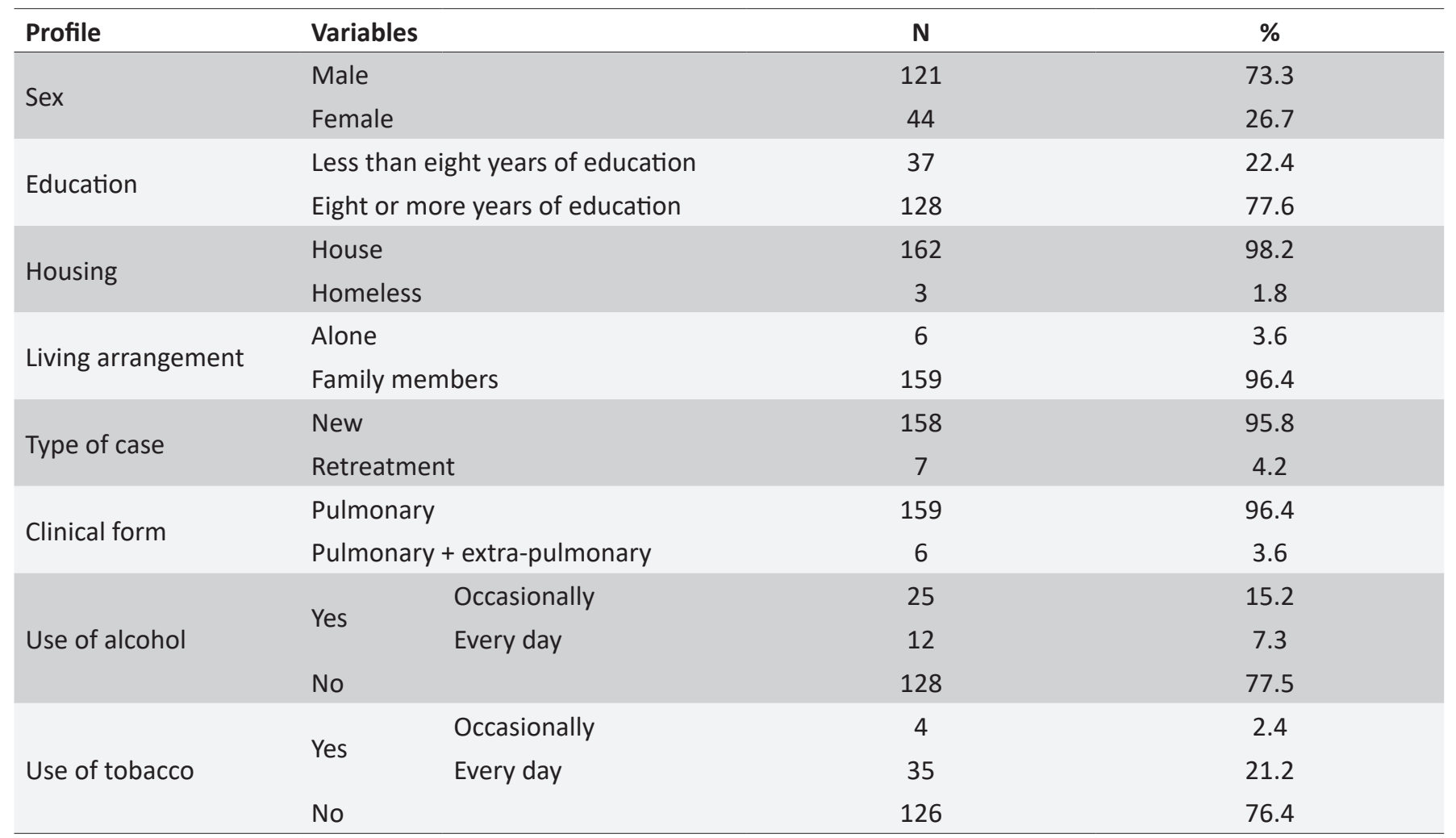

Table 2. Distribution of frequencies of the profile of the nursing professionals that assisted the tuberculosis cases in treatment, Campinas - São Paulo, Brazil, 2013.

\begin{tabular}{|c|c|c|c|}
\hline Profile of the nursing professionals & & $\mathbf{n}$ & $\%$ \\
\hline \multirow{2}{*}{ Professional category } & Nurse & 109 & 59.6 \\
\hline & Nursing aide/technician & 74 & 40.4 \\
\hline \multirow{2}{*}{ Sex } & Female & 158 & 86.3 \\
\hline & Male & 25 & 13.7 \\
\hline \multirow{2}{*}{$\begin{array}{l}\text { Searches for information about tuberculosis in books and/or on } \\
\text { the Internet }\end{array}$} & Yes & 161 & 88.0 \\
\hline & No & 22 & 12.0 \\
\hline \multirow{2}{*}{ Takes training courses to provide care to tuberculosis patients } & Yes & 136 & 74.3 \\
\hline & No & 47 & 25.7 \\
\hline
\end{tabular}

Individuals diagnosed with TB who receive detailed information about the disease and about the relevance of undergoing treatment to be cured, about the potential adverse reactions and the consequences of irregularly following treatment are more prone to adhere to treatment. ${ }^{16}$

Regarding guidance about the importance of attending monthly appointments and taking control exams, although patients and professionals report receiving/providing that action, respectively, not all services provided monthly medical appointments. In these cases, however, the TB patient was supported and assisted by the nursing team. Studies show that nurses are at the forefront of the work against TB, deeply understand the magnitude of adherence and the potential interventions to improve it, playing a core role in the programs on disease control, and are essential to assist the patient during treatment. ${ }^{17}$

Regarding how medications should be taken, the incentive to continue the TB treatment, the perceived improvement of symptoms during treatment and the conduct to be adopted if symptoms worsen have also presented concordance among respondents. This aspect shows that professionals are instructing the TB patients about how to conduct the treatment, making 
Table 3. Distribution of frequency of actions developed by the primary health care services to promote adherence to the tuberculosis treatment in the perception of patients and nursing professionals, Campinas - São Paulo, Brazil, 2013.

\begin{tabular}{|c|c|c|c|c|}
\hline Actions developed & & $\begin{array}{c}\text { Patient } \\
\text { n (\%) }\end{array}$ & $\begin{array}{c}\text { Professional } \\
\mathrm{n}(\%)\end{array}$ & $p$ \\
\hline \multirow{2}{*}{ 1. Guidance about tuberculosis } & Yes & $165(100.0)$ & $183(100.0)$ & \multirow{2}{*}{ - } \\
\hline & No & $0(0.0)$ & $0(0.0)$ & \\
\hline \multirow{2}{*}{$\begin{array}{l}\text { 2. Guidance to seek information about the disease in books } \\
\text { and/or on the Internet }\end{array}$} & Yes & $163(98.8)$ & $154(84.2)$ & \multirow{2}{*}{$<0.0001^{* \neq}$} \\
\hline & No & $2(1.2)$ & $29(15.8)$ & \\
\hline \multirow{2}{*}{ 3. Opportunity to speak about the treatment } & Yes & $92(55.8)$ & $172(94.0)$ & \multirow{2}{*}{$<0.0001^{* \ddagger}$} \\
\hline & No & $73(44.2)$ & $11(6.0)$ & \\
\hline \multirow{2}{*}{$\begin{array}{l}\text { 4. Scheduling of monthly medical appointments to monitor } \\
\text { treatment }\end{array}$} & Yes & $140(84.9)$ & 183(100.0) & \multirow{2}{*}{$<0.0001^{* \ddagger}$} \\
\hline & No & $25(15.1)$ & $0(0.0)$ & \\
\hline \multirow{2}{*}{$\begin{array}{l}\text { 5. Awareness-raising about the importance of keeping } \\
\text { monthly appointments }\end{array}$} & Yes & $163(98.8)$ & $183(100.0)$ & \multirow{2}{*}{$0.1352^{+}$} \\
\hline & No & $2(1.2)$ & $0(0.0)$ & \\
\hline \multirow{2}{*}{ 6. Guidance about undergoing control exams } & Yes & $163(98.8)$ & $182(99.5)$ & \multirow{2}{*}{$0.5023 *$} \\
\hline & No & $2(1.2)$ & $1(0.5)$ & \\
\hline \multirow{2}{*}{ 7. Guidance about how to take the tuberculosis medication } & Yes & $164(99.4)$ & $182(99.5)$ & \multirow{2}{*}{$0.9414^{+}$} \\
\hline & No & $1(0.6)$ & $1(0.5)$ & \\
\hline \multirow{2}{*}{ 8. Delivery of written information about the treatment } & Yes & $92(55.8)$ & $134(73.2)$ & \multirow{2}{*}{$0.0006^{* \neq}$} \\
\hline & No & $73(44.2)$ & $49(26.8)$ & \\
\hline \multirow{2}{*}{ 9. Encouragement to continue the tuberculosis treatment } & Yes & $163(98.8)$ & $182(99.5)$ & \multirow{2}{*}{$0.5023^{+}$} \\
\hline & No & $2(1.2)$ & $1(0.5)$ & \\
\hline \multirow{2}{*}{$\begin{array}{l}\text { 10. Guidance to seek the health service in case of doubts } \\
\text { about treatment }\end{array}$} & Yes & $164(99.4)$ & 181 (98.9) & \multirow{2}{*}{$0.6237^{+}$} \\
\hline & No & $1(0.6)$ & $2(1.1)$ & \\
\hline \multirow{2}{*}{$\begin{array}{l}\text { 11. Guidance to observe if symptoms improved during } \\
\text { treatment }\end{array}$} & Yes & $163(98.8)$ & $181(98.9)$ & \multirow{2}{*}{$0.9170^{+}$} \\
\hline & No & $2(1.2)$ & $2(1.1)$ & \\
\hline \multirow{2}{*}{$\begin{array}{l}\text { 12. Guidance about the conduct to be adopted if symptoms } \\
\text { worsen }\end{array}$} & Yes & $163(98.8)$ & $180(98.4)$ & \multirow{2}{*}{$0.7380^{+}$} \\
\hline & No & $2(1.2)$ & $3(1.6)$ & \\
\hline \multirow{2}{*}{ 13. Guidance to adopt healthier life habits } & Yes & $164(99.4)$ & $182(99.5)$ & \multirow{2}{*}{$0.9414^{+}$} \\
\hline & No & $1(0.6)$ & $1(0.5)$ & \\
\hline \multirow{2}{*}{$\begin{array}{l}\text { 14. Guidance for family members to undergo tuberculosis } \\
\text { exams }\end{array}$} & Yes & $158(95.8)$ & $182(99.5)$ & \multirow{2}{*}{$0.0216^{\dagger \neq}$} \\
\hline & No & $7(4.2)$ & $1(0.5)$ & \\
\hline 15. Time for the patient to talk about doubts and/or concerns & Yes & $158(95.8)$ & $182(99.5)$ & $0.0216^{\ddagger \ddagger}$ \\
\hline & No & $7(4.2)$ & $1(0.5)$ & \\
\hline 16. Performs/offers directly observed treatment & Yes & $129(78.2)$ & $143(78.1)$ & $<00001 * \ddagger$ \\
\hline 10. Pertorms/omers arrectiy onserved treatment & No & $36(21.8)$ & $40(2.9)$ & $<0.0001$ \\
\hline 17 Reroive/nrovidec incentivec to undergo the treatment & Yes & $147(89.1)$ & $162(88.5)$ & $\cap \cap \cap \cap 2 * \neq$ \\
\hline 1/. Receives/provides incentives to undergo the treatment & No & $18(10.9)$ & $21(11.5)$ & $0.0003^{1+t}$ \\
\hline 18 Invitation to particinato in a oroun of tuhorculocic nationtc & Yes & $59(35.8)$ & $58(31.7)$ & $01220 *$ \\
\hline 18. Invitation to participate in a group or tudercuiosis patients & No & $106(64.2)$ & $125(68.3)$ & $0.4229^{\circ}$ \\
\hline
\end{tabular}

${ }^{*}$ Chi-square test; ${ }^{\dagger}$ Fisher's exact test; ${ }^{*}$ statistical significance to the chi-square test or Fisher's exact test. 
patients the protagonist in the continuity of treatment. A study carried out in Africa ${ }^{17}$ shows that nurses are engaged in the practical work of informing patients about treatment, resulting symptoms and the importance of concluding the treatment to be cured. In Campinas ${ }^{8}$ in 2013, 86.3\% of the patients in treatment were cured, which should evidence the nurses' support to patients as a probable aspect that contributes to adherence.

The question of seeking a health service in case of doubts about the treatment also had concordant answers among respondents. When patients receive health care it builds a link between them and the professional/team, strengthening the relationship and thus favoring adherence to treatment, ${ }^{18}$ since doubts about the disease and treatment are clarified in these moments. In this sense, it is worth highlighting the nursing team's work in assisting patients and controlling the disease, ${ }^{17,19}$ where nurses are a participatory and crucial agent of the actions to organize TB care. ${ }^{19}$

As regards the adoption of healthier habits responses were concordant among the respondents, being typical to individuals more concerned about their improvement and that, therefore, adhere more to treatment. ${ }^{20}$ This study showed that most of the patients interviewed did not use tobacco and alcohol, which is an important factor to adherence to treatment, as also found in a study carried out in Fortaleza, in the state of Ceará. ${ }^{21}$

The health centers in the municipality of Campinas have groups to assist different types of conditions, but there is no group for TB patients although they and the professionals have reported offering/receiving this action, respectively. Therefore, this fact could have occurred due to patient participation in other groups in the HC.

In this study eight additional actions analyzed got discordant answers among respondents. Of these, seven point out a gap in the offer of these actions towards adherence to the TB treatment, since professionals said they offered these actions, but the TB patients have not perceived/received them. However, the variable "guidance to seek information about TB in books and/ or on the Internet" was perceived by patients more than the professionals effectively reported having offered it. This is an important aspect to adherence and a tool that contributes to increase the patients' knowledge about their health condition and then continue treatment, considering that literature ${ }^{22}$ points out that TB patients have insufficient knowledge about the disease, treatment, and treatment length.

Enabling the participation of TB patients in their treatment, granting them enough time to have their doubts/concerns clarified and giving opinions was not perceived by patients in the same way as informed by professionals. This was observed in other studies ${ }^{23,24}$ according to which most of the times TB patients are treated in an authoritarian manner, based on the health team's recommendations. This approach does not promote the autonomy of patients to make decisions about their treatment.
Regarding the scheduling of monthly appointments to monitor the treatment of TB patients, the professionals said it was envisioned but, nonetheless, it was not always implemented in the reality experienced by the TB patients due to the shortage of medical professionals in some $\mathrm{HC}$ in the municipality. A study developed in Belo Horizonte, Minas Gerais, ${ }^{22}$ shows gaps in guidance and scheduling of return visits which could hinder patient adherence to treatment.

Receiving written information about the treatment was less perceived by the TB patients than professionals said to offer it. The provision of written information helps adherence to treatment and should be straight and clear, as patients do not always assimilate and process the oral messages received and, so, written information may turn into behaviors. ${ }^{25}$

Although discordant, the percentage of guidance for family members to undergo TB exams exceeded $90 \%$ according to patients and professionals. This could have been facilitated by the fact that most patients interviewed lived with their family members. The investigation of contacts allows getting families closer to the team, including them in the treatment of TB patients ${ }^{19}$ and, therefore, collaborating to cope with the disease, and influencing habits to the continuity of and adherence to treatment.

The DOT offer was less perceived by patients than professionals said to offer. In 2013 the DOT was recommended to $71.5 \%$ of the TB patients in Campinas. ${ }^{8}$ and carried out to nearly $55 \%$ of the new cases ${ }^{9}$ This is in line with the information provided by the TB patients interviewed, considering that most of them were new cases with the pulmonary form of the disease.

A study carried out in a municipality of São Paulo ${ }^{26}$ in 2013 shows that the DOT has gradually increased over years, from $5.1 \%$ in 2000 to $86.6 \%$ in 2009 . This is a tool for successfully treating the disease, ${ }^{18}$ reducing the likelihood of abandonment and improving adherence to treatment and cure rates. ${ }^{27}$ In the PHC network the DOT may be facilitated since health professionals are closer to the community and the patients' social issues. ${ }^{28}$ However, there is still a challenge to expand the DOT coverage and sustainability due to difficulties such as shortage of human, material and financial resources that influence the disease control, among other health situations. ${ }^{29}$

Allied to the DOT, the offer of incentives is another important strategy of facilitation. According to data of the Ministry of Health ${ }^{30}$ of the 181 priority municipalities for TB control in Brazil, $44.8 \%$ provide one or more types of social benefit or incentive to adhere to TB treatment. In Campinas, breakfast kits were distributed to most of the TB patients, in addition to basic food boxes. This last was conditioned to an economic-social criterion.

Transportation vouchers were offered to a short number of patients $(1.2 \%)$ which might be attributed to the lack of knowledge about the law that grants TB patients this incentive in the municipality, or even because most of the patients lived 
near the HC. However, exams such as x-ray and appointments with specialists are performed in far services. The transportation voucher facilitates the displacement of TB patients to the health services to control treatment (appointments) and DOT monitoring, as well as to undergo exams, whenever required, improving adherence to treatment. ${ }^{31}$

According to literature, ${ }^{32,33}$ incentives granted and the care provided by the professional who supervised the DOT ensure better adherence to treatment and offer the opportunity to identify other needs related to their life, social and economic condition, links with family members, co-responsibility, support, referrals, needs, and also build links with the health team in charge of supervision.

The actions developed in PHC to promote adherence to TB treatment may provide inputs to understand emerging issues in face of a reality where patients have 'free' access to medication therapeutics, but do not adhere to treatment. ${ }^{34}$ Therefore, to ensure TB patients' adherence to treatment, professionals must be familiar with the user's singular needs and develop co-responsibility in care, consistently reinforcing the patients' motivation, strengthening the importance of adherence. ${ }^{32,33}$

As limitations to this study, there is a potential selection bias as some TB patients were not found or were excluded from the study by the team assisting them.

\section{CONCLUSION}

The analysis of the perceptions of TB patients and nursing professionals about the actions developed in the PHC services in the municipality of Campinas to promote adherence to TB treatment shows that respondents were concordant regarding guidance on the disease and its treatment, assistance of the nursing team during treatment with guidance about the disease and its prevention. The respondents had discordant answers regarding guidance about the disease and its prevention, empowerment during treatment, offer of actions on nursing monitoring such as the DOT and incentives. This discordance shows a mismatch between what health professionals say to be offered and what is effectively received by patients. However, it is worth mentioning the set of actions offered by the nursing team that worked in actions to support adherence to TB treatment.

\section{REFERENCES}

1. Ferreira JEE, Engstron L, Alves LC. Adesão ao tratamento da tuberculose pela população de baixa renda moradora de Manguinhos, Rio de Janeiro: as razões do im(provável). Cad Saúde Colet. 2012 Apr/ Jun;20(2):211-6.

2. Ministério da Saúde (BR). Fundação Nacional de Saúde. Plano Nacional de Controle da Tuberculose. Brasília (DF): Ministério da Saúde; 2004.

3. Ministério da Saúde (BR). Secretaria de Vigilância em Saúde. Boletim Epidemiológico. Brasília (DF): Ministério da Saúde [Internet] 2016;47(13). [cited 2016 Mar 11] 15 p. Available from: http://portalsaude. saude.gov.br/images/pdf/2016/marco/24/2016-009-Tuberculose-001. pdf
4. World Health Organization (WHO). Adherence to long-term therapies Evidence for action [Internet]. Geneva: World Health Organization 2003. [cited 2014 May 14] 151 p. Available from: http://www.who.int/ chp/knowledge/publications/adherence_introduction.pdf

5. Ferreira RCZ, Ramdohr Sobrinho EC, Zóia EN, Figueiredo RM. Perfi epidemiológico da tuberculose em município do interior paulista (20012010). CuidArte Enferm. 2013 Jan/Jun;7(1):7-12

6. Ministério da Saúde (BR). Secretaria de Vigilância em Saúde Departamento de Vigilância das Doenças Transmissíveis. Panorama da Tuberculose no Brasil: indicadores epidemiológicos e operacionais. Brasília (DF): Ministério da Saúde; 2014.

7. Oliveira IC, Jesus GJ, Pinto PFPS, Balderrama P, Cury MRCO, Vendramini SHF. Tuberculosis control: evaluation of the nursing team on the framework of health services. Rev Enferm UFPE on line [Internet] 2012 Sep; [cited 2017 Jun 29]; 6(9):2145-53. Available from: http:// www.revista.ufpe.br/revistaenfermagem/index.php/revista/article/ viewArticle/2580. DOI: 10.5205/reuol.2570-20440-1-LE.0609201219

8. Sala de Situação do Estado de São Paulo [Internet]. São Paulo (SP); 2015 [cited 2017 Ago 2]. Available from: http://www.tuberculose.saude. sp.gov.br/

9. Sistema de Notificação e Acompanhamento dos Casos de Tuberculose. TB-WEB [Internet]. São Paulo (SP);2015 [cited 2015 Mar 05]. Restricted Acess. Available from: http://www.cvetb.saude.sp.gov.br/tbweb/index.jsp

10. Ministério da Saúde (BR). Secretaria de Vigilância em Saúde. Departamento de Vigilância Epidemiológica. Manual de recomendações para o controle da tuberculose no Brasil. Brasília (DF): Ministério da Saúde [Internet]. 2011. [cited 2015 Mar 05]. Available from: http://bvsms. saude.gov.br/bvs/publicacoes/manual_recomendacoes_controle_ tuberculose brasil.pdf

11. Williams G, Alarcon E, Jittimanee S, Walusimbi M, Sebek M, Berga E et al. Care during the intensive phase: promotion of adherence. Int $J$ Tuberc Lung Dis [Internet]. 2008 Jun; [cited 2012 Feb 08]; 12(6):6015. Available from: http://www.ingentaconnect.com/content/iuatld/ ijtld/2008/00000012/00000006/art00005

12. Williams G, Alarcon E, Jittimanee S, Walusimbi M, Sebek M, Berga $E$, et al. Starting treatment: caring for patients and their families. Int $J$ Tuberc Lung Dis [Internet]. 2008 May; [cited 2012 Feb 08]; 12(5):4937. Available from: http://www.ingentaconnect.com/content/iuatld/ ijtld/2008/00000012/00000005/art00004

13. Jin J, Sklar GE, Sen Oh VM, Li SC. Factors affecting therapeutic compliance: A review from the patient's perspective. Ther Clin Risk Manag [Internet]. 2008 Feb; [cited 2012 Feb 08]; 4(1):269-86. Available from: http://www.ncbi.nlm.nih.gov/pmc/articles/PMC2503662/

14. Gonçalves H, Costa JSD, Menezes AMB, Knauth D, Leal OF. Adesão à terapêutica da tuberculose em Pelotas, Rio Grande do Sul: na perspectiva do paciente. Cad. Saude Publica [Internet]. 1999 Oct; [cited 2015 Fev 15]; 15(4):777-87. Available from: http://www.scielo.br/scielo. php?script=sci_arttext\&pid=S0102-311X1999000400012\&Ing=en. DOI 10.1590/S0102-311X1999000400012

15. Siegel S, Castellan NJ Jr. Nonparametric Statistics for the Behavioral Sciences. New York: McGraw-Hill; 1988. 399 p.

16. Costa SM, Mendoza-Sassi RA, Teixeira TP, Leivas VA, Cézar-Vaz MR Conhecimento dos clientes com tuberculose pulmonar e seus familiares sobre adesão ao tratamento e fatores associados, no município do Rio Grande (RS). Ciênc Saúde Coletiva [Internet]. 2011; [cited 2015 Feb 15]; 16(Suppl 1):1427-35. Available from: http://www.scielo.br/scielo. php?script=sci_arttext\&pid=S1413-81232011000700078\&Ing=en. DOI: 10.1590/S1413-81232011000700078

17. Carlsson M, Johansson S, Eale RPB, Kaboru BB. Nurses Roles and Experiences with Enhancing Adherence to Tuberculosis Treatment among Patients in Burundi: A Qualitative Study. Tuberc Res Treat [Internet]. 2014 [cited 2017 Aug 16];2014:984218. Available from: https://www.ncbi.nlm. nih.gov/pmc/articles/PMC4152946/. DOI: 10.1155/2014/984218

18. Nogueira JA, Oliveira LCS, Sá LD, Silva CA, Silva DM, Villa TCS. Vínculo e acesso na Estratégia Saúde da Família: percepção de usuários com tuberculose. Rev Rene [Internet]. 2012 Sep-Dec; [cited 2015 Feb 15]; 13(4):784-93. Available from: http://www.redalyc.org/articulo. oa?id=324027983008 
19. Rêgo CCD, Macêdo SM, Andrade CRB, Maia VF, Pinto JTJM, Pinto ESG. Processo de Trabalho do enfermeiro junto à pessoa com tuberculose na Atenção Primária à Saúde. Rev. Baiana Enferm [Internet]. $2015 \mathrm{Jul} / \mathrm{Sep}$; [cited 2016 Jun 16]; 29(3):218-28. Available from: https://portalseer.ufba.br/index.php/enfermagem/article/ view/13038. DOI: $10.18471 /$ rbe.v29i3.13038

20. Souza Filho MP, Luna IT, Silva KL, Pinheiro Costa PN. Pacientes vivendo com HIV/AIDS e coinfecção tuberculose: dificuldades associadas à adesão ou ao abandono do tratamento. Rev Gaucha Enferm [Internet]. 2012 Jun; [cited 2015 Feb 15]; 33(2):13945. Available from: http://www.scielo.br/scielo.php?script=sci arttext\&pid=S1983-14472012000200020\&Ing=en. DOI: $10.1590 /$ S1983-14472012000200020

21. Wendling APB, Modena CM, Schall VT. Abandonment of tuberculosis treatment in the perspective of health centers managers in Belo Horizonte-MG, Brazil. Texto Contexto Enferm [Internet]. 2012 Mar; [cited 2015 Feb 15]; 21(1):77-85. Available from: http://www.scielo.br/scielo. php?script=sci_arttext\&pid=S0104-07072012000100009\&lng=en . DOI: $10.1590 / S 0104-07072012000100009$

22. Orfão NH, Andrade RLP, Beraldo AA, Brunello MEF, Scatena LM, Villa TCSAdherence therapeutic to the treatment of tuberculosis in a municipality of the São Paulo state. Ciênc Cuid Saúde [Internet]. 2015 Oct/Dec; [cited 2017 Jun 29]; 14(4):1453-61. Available from: http:// dx.doi.org/10.4025/cienccuidsaude.v14i4.25093

23. Souza KMJ, Sá LD, Silva LMC, Palha PF. Nursing performance in the policy transfer of directly observed treatment of tuberculosis. Rev Esc Enferm USP [Internet]. 2014 Oct; [cited 2016 Dec 16]; 48(5):87482. Available from: http://www.scielo.br/scielo.php?script=sci arttext\&pid=S0080-62342014000500874\&Ing=en. DOI: $10.1590 /$ S0080-6234201400005000014

24. Oliveira AAV, Sá LD, Nogueira JA, Andrade SLE, Palha PF, Villa TCS. Tuberculosis diagnosis in older people: barriers to accessing health services. Rev Esc Enferm USP [Internet]. 2013 Fev; [cited 2016 Dec 16]; 47(1):142-8. Available from: http://www.scielo.br/scielo. php?script=sci_arttext\&pid=S0080-62342013000100018\&lng=en. DOI: 10.1590/S0080-62342013000100018

25. Marcolino ABL, Nogueira JA, Ruffino-Netto A, Moraes RM, Sá LD, Villa TCS, et al. Avaliação do acesso às ações de controle da tuberculose no contexto das equipes de saúde da família de Bayeux - PB. Rev Bras Epidemiol [Internet]. 2009 Jun; [cited 2015 Feb 15]; 12(2):14457. Available from: http://www.scielo.br/scielo.php?script=sci arttext\&pid=S1415-790X2009000200005\&lng=en. DOI: $10.1590 /$ S1415-790X2009000200005

26. Hino P, Takahashi RF, Bertolozzi MR, Egry EY. A ocorrência da tuberculose em um distrito administrativo do município de São Paulo. Esc Anna Nery [Internet]. 2013 Jan-Mar; [cited 2015 Feb 15];
17(1):153-9. Available from: http://www.scielo.br/scielo.php?script=sci arttext\&pid=S1414-81452013000100021\&lng=en. DOI: $10.1590 /$ S1414-81452013000100021

27. Reis-Santos B, Pellacani-Posses I, Macedo LR, Golub JE, Riley LW, Maciel EL. Directly observed therapy of tuberculosis in Brazil: associated determinants and impact on treatment outcome. Int J Tuberc Lung Dis. [Internet]. 2015 Oct; [cited 2017 Jun 29]; 19(10):1188-93. Available from: http://dx.doi.org/10.5588/ijtld.14.0776

28. Bartholomay P, Pelissari DM, Araujo WN, Yadon ZE, Heldal E. Quality of tuberculosis care at different levels of health care in Brazil in 2013. Rev Panam Salud Publica [Internet]. 2016 Jan; [cited 2016 Dec 15]; 39(1):3-11. Available from: http://www.scielosp.org/scielo. php?script=sci_arttext\&pid=S1020-49892016000100003\&lng=en

29. Wikman-Jorgensen PE, Morales-Cartagena A, Llenas-García J, PérezPorcuna TM, Hobbins M, Ehmer J, et al. Implementation challenges of a TB programme in rural northern Mozambique: evaluation of 20122013 outcomes. Pathog Glob Health [Internet]. 2015 Jul; [cited 2017 Jun 29]; 109(5):221-7. Available from: http://doi.org/10.1179/2047773 215Y.0000000027

30. Ministério da Saúde (BR). Secretaria de Vigilância em Saúde. Boletim Epidemiológico. Brasília (DF): Ministério da Saúde [Internet].2015;46(9); [cited 2016 Dec 15]; 19 p. Available from: http://portalarquivos.saude.gov. br/images/pdf/2015/marco/25/Boletim-tuberculose-2015.pdf

31. Bellenzani R, Nemes MIB, Paiva V. Health professional-patient communication and care: evaluation of an intervention for HIV/AIDS treatment adherence. Interface (Botucatu) [Internet]. 2013 Dec; [cited 2015 Dec 10]; 17(47):803-34. Available from: http://www.scielo.br/scielo. php?script=sci_arttext\&pid=S1414-32832013000400005\&lng=en . DOI: 10.1590/1807-57622013.0051

32. Sá LD, Santos ARBN, Oliveira AAV, Nogueira JA, Tavares LM, Villa TCS. Providing health care to women with tuberculosis: the family focus perspective. Texto Contexto Enferm [Internet]. 2012 Jun; [cited 2016 Dec 13]; 21(2):409-17. Available from: http://www.scielo.br/scielo. php?script=sci_arttext\&pid=S0104-07072012000200020\&lng=en . DOI: 10.1590/S0104-07072012000200020

33. Hino P, Takahashi RF, Bertolozzi MR, Villa TCS, Egry EY. Family health team knowledge concerning the health needs of people with tuberculosis. Rev Latino-Am Enfermagem [Internet]. 2012 Feb; [cited 2015 Dec 10]; 20(1):44-51. Available from: http://www.scielo.br/scielo. php?script=sci_arttext\&pid=S0104-11692012000100007\&lng=en . DOI: $10.1590 / S 0104-11692012000100007$

34. Dias Fortesa P. A justa dose da medida: o tratamento compulsório da tuberculose em questão. Interface (Botucatu) [Internet]. 2016 Jul/Sep; [cited 2017 Jun 29]; 20(58):743-51. Available from: http:// www.redalyc.org/articulo.oa?id=180146193018. DOI: 10.1590/180757622015.0775 